УДК 636.8:636.7:619:616

(C) 2014

\author{
Локес П. І., доктор ветеринарних наук, \\ Кравченко С. О., кандидат ветеринарних наук, \\ Локес-Крупка Т. П., магістр ветеринарної медицини, \\ Бурда Т. Л., матістр ветеринарної медицини
}

Полтавська державна аграрна академія

\title{
МОРФОЛОГІЧНІ ЗМІНИ ПЕЧІНКИ ЗА ГЕПАТИТУ У СОБАК І КОТІВ
}

\author{
Рецензент - доктор ветеринарних наук, професор М. В. Скрипка
}

Дослідженнями встановлено, що за розвитку гепатиту у собак та домашніх котів у печіниі запальний прочес перебігає у двох формах - серозній та геморагічній. Макроскопічно печінка збільшена та набрякла, їі краї - притуплені, капсула напружена, реєструються застійні явища. На розрізі малюнок стертий. Зміни в судинах за обох форм патології аналогічні. Запальний набряк більи виражений за серозної форми гепатиту в котів. В обох випадках відбувається гіпертрофія $i$ гіперплазія клітин Купфера та зерниста дистрофія гепатоицитів.

Ключові слова: собаки, коти, морфологія, печінка, гепатит.

Постановка проблеми. Захворювання печінки запального характеру у собак і домашніх котів складають значну частину внутрішньої незаразної патології тварин цих видів [1-4]. Проблема полягає у тому, що хвороби печінки запального характеру часто перебігають субклінічно, що ускладнює встановлення діагнозу та вибір напряму лікування. Клінічні симптоми у таких випадках дають недостатньо інформації для аналізу, тому необхідним є застосування додаткових методів досліджень, таких як ультрасонографія, лабораторні дослідження біологічних субстратів. Проте для наукового пошуку важливим $\epsilon$ поєднання результатів клініко-лабораторних досліджень та аналізу структурних змін печінки.

Таким чином, вивчення морфологічних змін печінки за гепатиту в собак та котів $є$ актуальним питанням.

Аналіз основних досліджень і публікацій, у яких започатковано розв'язання проблеми. Гепатит $є$ одним із найбільш розповсюджених захворювань як серед людей, так і свійських тварин, зокрема собак і котів. Саме у тварин цих видів часто спостерігають гострий перебіг гепатиту, за якого виникає запалення печінки дифузного характеру, що супроводжується ексудативними, альтернативними i проліферативними процесами у стромі органа, гіперемією, клітинною інфільтрацією, дистрофічними й некротич- ними змінами гепатоцитів та інших структурних елементів і різко вираженою печінковою недостатністю [5-7]. Проте морфологія печінки за гепатиту у собак та домашніх котів досі висвітлена недостатньо, тому дослідження у даному науковому напрямі $є$ вкрай необхідними.

Мета і завдання дослідження. Мета дослідження - вивчення морфологічних змін печінки собак і котів за гепатиту.

Основним завданням було вивчення мікроскопічних змін клітин печінки за вказаної патології.

Матеріали і методи. Дослідження проводили в умовах кафедри терапії Полтавської державної аграрної академії. У випадках загибелі собак та котів із діагнозом «гепатит» вивчали патологоанатомічні зміни та проводили відбір матеріалу (проби печінки) для подальших гістологічних досліджень.

Гістологічні дослідження печінки проводили на базі кафедри патологічної анатомії та інфекційної патології Полтавської державної аграрної академії (за консультативної допомоги доктора ветеринарних наук, професора М. В. Скрипки).

Шматочки печінки досліджених тварин розміром $1 \times 1 \times 1$ см фіксували $10 \%$ нейтральним розчином формаліну впродовж однієї-двох діб, потім зневоднювали у спиртах зростаючої концентрації (від $50^{0}$ до абсолютного). Отримані зразки після фіксації та зневоднення заливали в парафін за класичною методикою [8]. 3 отриманих блоків за допомогою санного мікротома виготовляли серійні зрізи товщиною 7,5 мкм, фарбували гематоксилін-еозином та стабілізували у полістиролі. Характерні патогістологічні зміни в гістопрепаратах фотографували на мікроскопі МБІ-3 3 мікрофотонасадкою МФН-12.

Матеріалом для досліджень слугували собаки та коти, які загинули внаслідок гепатиту, діагностованого на основі клінічних та біохімічних досліджень.

У ході виконання роботи використано матеріал, 


\section{ВЕТЕРИНАРНА МЕДИЦИНА}

відібраний у трупів чотирьох собак та чотирьох домашніх котів. Гістологічно було досліджено секційний матеріал від шести тварин (трьох собак та трьох котів).

Результати досліджень. У тварин, які загинули внаслідок гепатиту, відмічали, що печінка була збільшена та набрякла, іiі краї - притуплені, капсула напружена. Місцями виявляли ділянки синюшного кольору та застійні явища. На розрізі малюнок був стертий, поверхня розрізу - тьмяна, 3 поверхні розрізу виділялась рідина темночервоного кольору. У всіх тварин виявляли виразні морфологічні зміни як у печінці, так і в нирках. На поверхні печінки знаходили ділянки світло-сірого та сіро-коричневого кольору різних розмірів і форми. На розрізі малюнок був згладжений, поверхня розрізу - тьмяна.

Гепатит морфологічно проявлявся серозним та геморагічним запаленням паренхіми печінки.

Під час проведення гістологічних досліджень реєстрували розширення та переповнення кров'ю судин печінки, особливо судин тріад. Такі зміни супроводжувалися застоєм крові в артеріях і венах, що в багатьох випадках морфологічно проявлялось коагуляцією та зростанням концентрації білкових речовин, які дифузно чи у вигляді ніжноволокнистої сіточки забарвлювались еозином (рис. 1).
У міжчасточковій сполучній тканині органа та всередині часточок констатували накопичення серозного ексудату (рис. 1, рис. 2). За високого вмісту в ексудаті білкових речовин він також забарвлювався еозином, що зазвичай особливо проявлялось у печінкових часточках. Під час цього відбувалося виразне збільшення відстані між пластинками гепатоцитів (рис. 2). Усі гепатоцити перебували у стані зернистої дистрофії. Вони були нерівномірно збільшені, цитоплазма їх - набрякла, каламутна, нерівномірно зафарбована, з дрібними ацидофільними білковими зернами. Межі клітин та їх ядра важко диференціювалися або були зовсім непомітні. Також реєстрували гіперплазію та гіпертрофію Купферовських клітин.

За геморагічного гепатиту (у двох випадках) печінка мала виражений темно-червоний колір. Під час проведення гістологічних досліджень зміни в судинах (артеріях та венах) печінки були аналогічними тим, що й за серозного гепатиту (рис. 3). Запальний набряк реєстрували як у міжчасточковій сполучній тканині, так і всередині часточок, але він був не таким виразним. Поряд із цим, як і за серозного гепатиту, відмічали гіпертрофію та гіперплазію Купферовських клітин, а також зернисту дистрофію гепатоцитів.

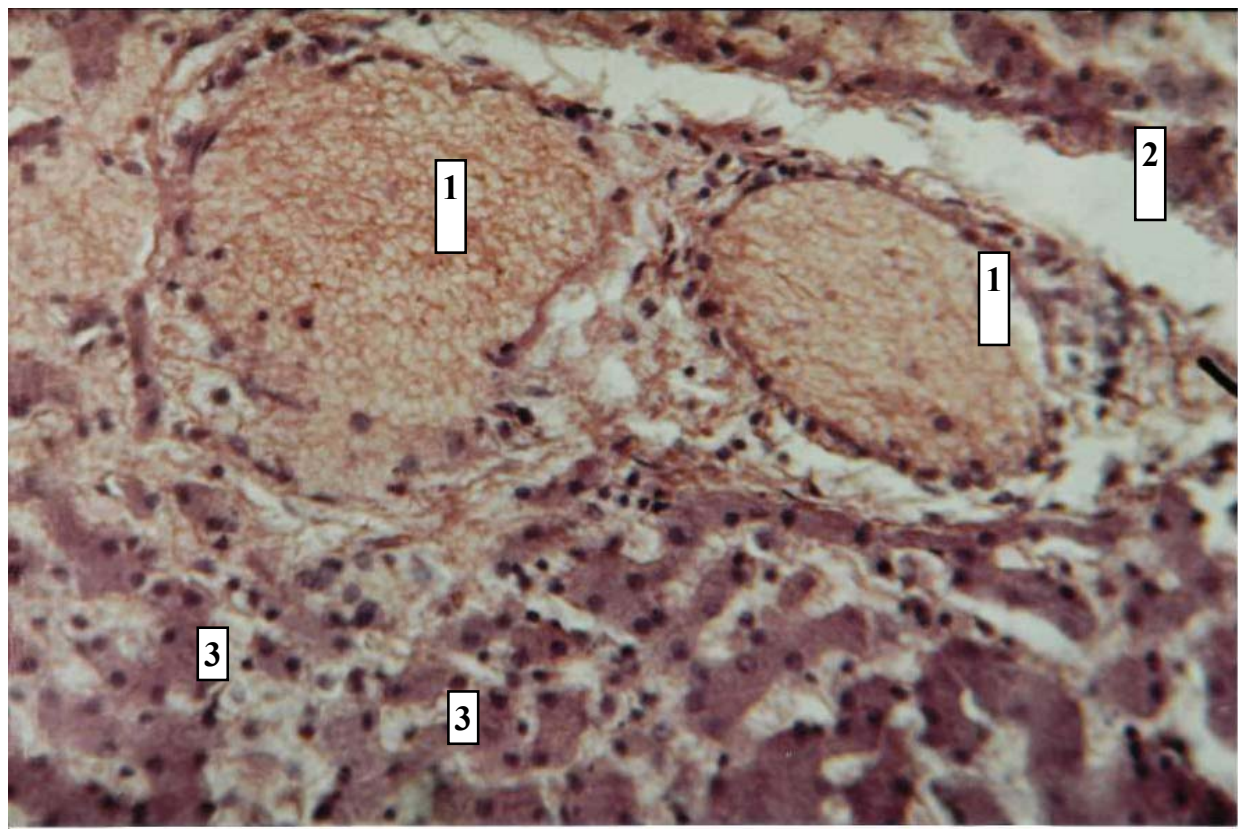

Рис. 1. Мікроскопічна будова печінки кота віком 3 роки:

1 - повнокрів'я венозних судин печінкової тріади;

2 - накопичення серозного ексудату в міжчасточковій сполучній тканині;

3 - зерниста дистрофія гепатоцитів. Забарвлення гематоксиліном Караці та еозином. Зб. × 200 


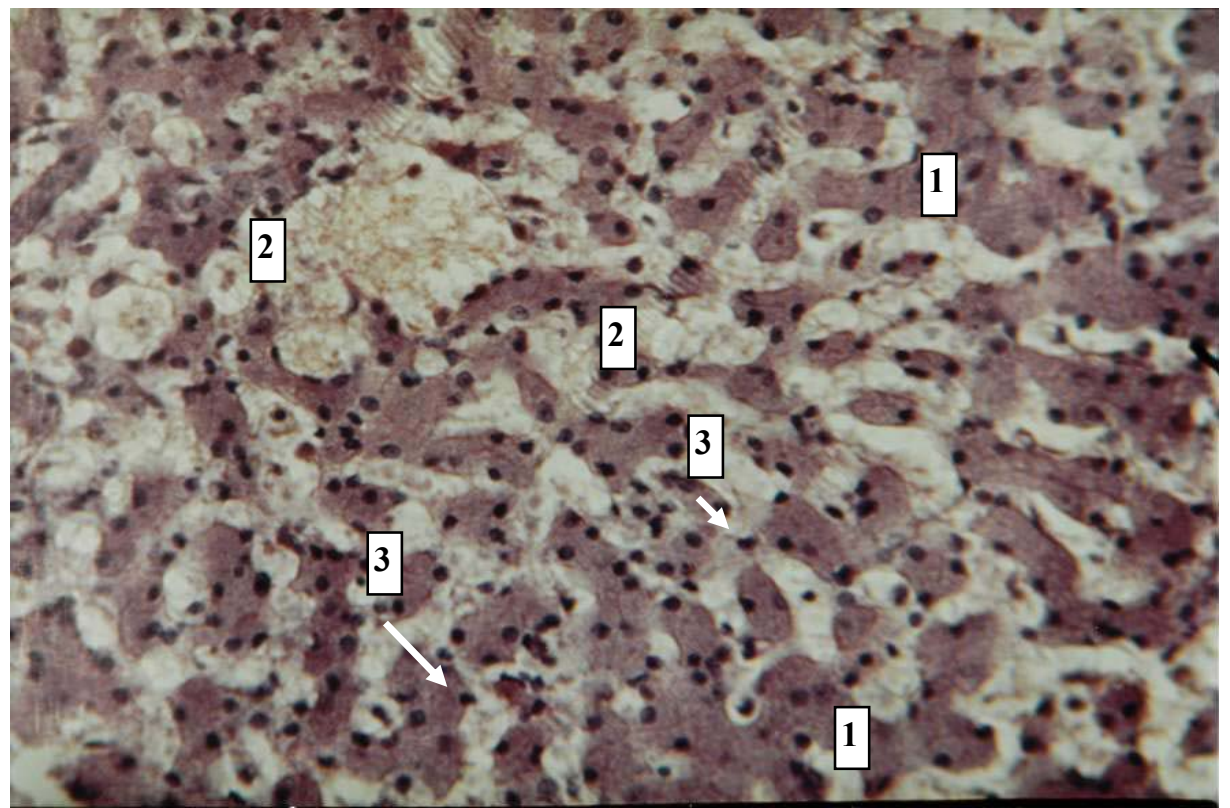

Рис. 2. Мікроскопічна будова печінки собаки віком 5 років:

1 - зерниста дистрофія гепатоцитів;

2 - скупчення серозного ексудату між балками гепатоцитів;

3 - Купферовські клітини. Забарвлення гематоксиліном Караці та еозином. Зб. × 200

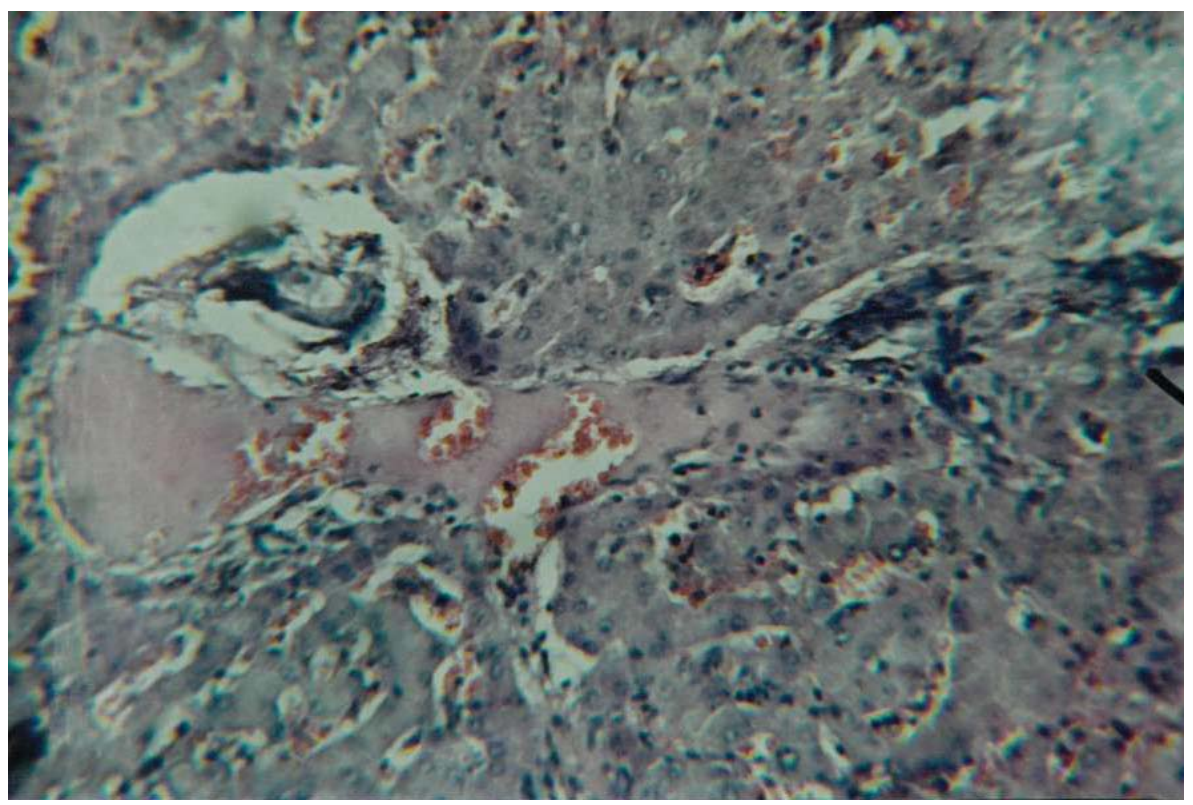

Рис. 3. Мікроскопічна будова печінки кота віком 5 років:

1 - зерниста дистрофія гепатоцитів;

2 - периваскулярний набряк печінкової тріади;

3 - частковий гемоліз еритроцитів артерії тріади;

4 -підвищене кровонаповнення синусоїдних капілярів. Забарвлення гематоксиліном Караці та еозином. Зб. $\times 200$ 


\section{ВЕТЕРИНАРНА МЕДИЦИНА}

Одержані гістологічні дані свідчать, що в собак та котів, які були об'єктами морфологічних досліджень, гепатит перебігав у двох формах серозній та геморагічній. Зміни в судинах за обох форм патології були аналогічними. Проте запальний набряк був більш вираженим за серозної форми гепатиту в котів. В обох випадках спостерігали гіпертрофію та гіперплазію клітин

\section{БІБЛІОГРАФІЯ}

1. Болезни собак и кошек. Комплексная диагностика и терапия болезней собак и кошек : учеб. пособие / [Т. К. Донская Г. Г. Щербаков, Г. В. Полушин] ; под ред. С. В. Старченкова. СПб. : Спец. литература, 2006. -655 с.

2. Чандлер Е. А. Болезни кошек / Е. А. Чандлер, К. Дж. Гаскелл, Р. М. Гаскел : пер. с англ. М. : Аквариум, 2002. - 696 с.

3. Болезни печени и желчевыводящих путей: Руководство для врачей : [под ред. В. Т. Ивашкина]. - М. : ООО «Издатдом М-Вести», 2002. $416 \mathrm{c}$.

4. Уша Б. В. Болезни печени собак / Б. В. Уша, И. П. Беляков. - М. : ПАЛЬМАпресс, 2002. - 36 с.
Купфера і зернисту дистрофію гепатоцитів.

Висновок. Таким чином, результати дослідження собак та котів, хворих на гострий паренхіматозний гепатит, свідчать про серозний і геморагічний перебіг запального процесу. Явища запального набряку більш виражені за серозної форми гепатиту у котів. Отже, гепатит у котів мав більш тяжкий перебіг, аніж у собак.

5. Ниманд Х. Г. Болезни собак / Х. Г. Ниманд, П. Б. Сутер : пер. с англ. - М. : Аквариум ЛТД, 2001. - C. 604-608.

6. Внутрішні хвороби тварин / [В. І. Левченко, І. П. Кондрахін, В. В. Влізло та ін.] ; за ред. В. І. Левченка. - Біла Церква, 2012. - Ч. 1. $528 \mathrm{c}$.

7. Кондрахин И. П. Диагностика и терапия внутренних болезней животных / И. П. Кондрахин, В. И. Левченко. - М. : Аквариум-Принт, 2005. $-830 \mathrm{c}$.

8. Меркулов А. Б. Курс патогистологической техники / А. Б. Меркулов. - Л. : Медицина, 1969. $-237 \mathrm{c}$. 